\title{
Bazı makarnalık buğday genotiplerinde (Triticum durum L.) artan su stresinde morfolojik ve fizyolojik tepkilerin incelenmesi
}

\section{An assessment on morphological and physiological response to increasing water stress for some of durum wheat (Triticum durum L.) genotypes}

\author{
Büşra AKIN ${ }^{1 *}$, Merve BAYHAN² ${ }^{\text {iD }}$, Remzi ÖZKAN ${ }^{3}$ iD, Cuma AKINCI $^{4}$ (D) \\ 1,2,3,4 Dicle Üniversitesi, Ziraat Fakültesi, Tarla Bitkileri Bölümü, Diyarbakır

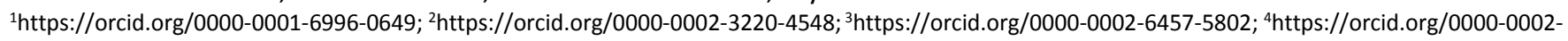 \\ 3514-1052
}

\section{To cite this article:}

Akın, B., Bayhan, M., Özkan, R. \& Akıncı, C. (2021). Bazı makarnalık buğdayda (Triticum durum L.) artan su stresinde morfolojik ve fizyolojik tepkilerin incelenmesi. Harran Tarım ve Gıda Bilimleri Dergisi, 25(2): 265-278.

DOI: $10.29050 /$ harranziraat.915372

${ }^{*}$ Address for Correspondence: Büşra AKIN e-mail:

busraakin736@gmail.com

Received Date:

13.04.2021

Accepted Date:

25.05.2021 öz

Kuraklık, bitkisel üretimi ve verimi sınırlayan en önemli faktörlerden biridir. Bitkiler, kuraklık stresiyle mücadele etmek için çeşitli morfolojik, fizyolojik, biyokimyasal ve moleküler tepkiler gösterirler. Çalışmada, makarnalık buğdayda artan su stresi altında genotipik farklılıkların belirlenmesi, su kullanım etkinliği ve verimle ilişkili olabilecek morfolojik ve fizyolojik parametrelerin incelenmesi amaçlanmıştır. Deneme, Dicle Üniversitesi Ziraat Fakültesi araştırma serasında, saksılarda kontrollü koşullarda yürütülmüştür. Araştırmada 7 tane makarnalık buğday genotipi (DZ7-51, Fırat-93, Hat-300, Sena, Svevo, TBT16-7 ve TBT16-9) kullanılmıştır. Tarla kapasitesine göre belirlenen artan su stresinde (\%100 Tarla Kapasitesi (TK), \%75TK, \%50TK ve \%25TK) buğday genotiplerinin morfolojik, fizyolojik, verim öğeleri ve kalite değişimleri incelenmiştir. Yaprak kıvrılması tüm su kısıtlama seviyelerinde verimle olumsuz yönde ilişkili bulunmuştur. Su stresindeki artışa bağlı olarak mumsuluk artış göstermiş ve \%50TK ve \%25TK su kısıtlama seviyelerinde verimle ilişkili bulunmuştur. Artan kuraklık düzeyleri, genotiplerin morfolojik, fizyolojik, verim öğelerinde azalışa neden olurken, protein oranına pozitif bir etki yapmıştır. Tane verimi ve biyomas yönünden hesaplanan su kullanım etkinliği değerleri su stresi arttıkça önemli düzeyde artış göstermiştir. Çalışmada incelenen morfolojik ve fizyolojik özellikler içerisinde mumsuluğun kuraklığa dayanıklıkta morfolojik markör olarak kullanılma potansiyeline sahip olabileceğini göstermiştir. DZ7-51 ve Fırat-93 genotipleri su stresine en çok dayanıklı genotipler olarak belirlenmiştir.

\section{Anahtar Kelimeler: Makarnalık buğday, Kuraklık, Stres, Su kullanım etkinliği}

\section{ABSTRACT}

One of the most significant factors restricting crop production and yield is drought. Plants may be able to adapt through several morphological, physiological, biochemical, and molecular responses while under drought stress. The aim of this experiment was to investigate the genetic differences in durum wheat under water stresses and to review their morphological and physiological parameters. 7 durum wheat genotypes (DZ7-51, Fırat-93, Hat-300, Sena, Svevo, TBT16-7 and TBT16-9) were used in the study. The experiment was performed under controlled conditions in a research greenhouse at Dicle University's Faculty of Agriculture. Morphological, physiological, yield components and quality changes of wheat genotypes with increased water stress (100\% Field Capasity (FC), 75FC\%, 50FC\% and 25FC\%) determined by field capacity were examined. Leaf rolling was, however, negatively correlated with yield at all level of water stress. Due to the rise in water stress, waxiness increased and was found to be correlated with yield at 50FC\% and 25 FC\% levels of water stress. Although increasing drought levels triggered a decrease in the morphological, physiological and yield components of the genotypes, they had a positive impact on the protein ratio. As water stress increased, water use efficiency values calculated according to grain yield and biomass weight increased significantly. Among the morphological and physiological characteristics examined in the study, it has shown that glaucousity can have the potential to be used as a morphological marker in drought resistance Genotypes of the DZ7-51 and Firat-93 wheat genotypes were found to be most resilient to water stress.

Key Words: Durum wheat, Drought, Stress, Water use efficiency
(C) Copyright 2018 by Harran University Faculty of Agriculture. Available on-line at www.dergipark.gov.tr/harranziraat

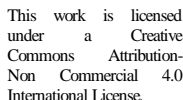




\section{Giriş}

Kuraklık ve aşırı sıcaklıklar, dünyada özellikle de kuru tarım sistemlerinde tahıl üretiminin önündeki en büyük abiyotik kısıtlamalardandır. Küresel iklim değişikliğinden dolayı değişen çevresel özellikler ve artan dünya nüfusundan dolayı bitkisel üretim ve su kaynakları gün geçtikçe tükenmektedir (Hossain ve ark., 2013). Sürekli artan gıda talebini karşılamak için sıcaklığa ve kuraklığa dayanıklı buğday genotiplerinin geliştirilmesi bitki ıslahçıları için zorunlu olmuştur (Hossain ve ark., 2013).

Ekmeklik (Triticum aestivum L.) ve makarnalık buğday (Triticum durum Desf) insanlık tarafından yetiştirilen ilk bitkilerden biridir (Haider, 2013). Mısır ve çeltikten sonra yıllık 762 milyon ton üretimle üçüncü büyük tahıl ürünü olarak yer almaktadır (FAO, 2019). Buğday, dünyada yaklaşık 2 milyar insan için temel bir gıda maddesidir. Ancak bu kadar değerli olan bu ürün günümüzde kuraklık ve sıcaklık stresinden ciddi bir şekilde etkilenmektedir (Turral ve ark., 2011). Dünyadaki toplam ekili alanın üçte birinden fazlası kuraklık stresinden etkilenmektedir. Bu alanın \%33'ü (99 milyon hektar) gelişmekte olan ülkelere ve $\% 25$ 'i (60 milyon hektar) ise gelişmiş ülkelere aittir (Rijsberman, 2006). 2050 yılına kadar öngörülen nüfusun gıda ihtiyaçlarını karşılamak için pirinç, buğday ve mısır gibi başlıca tahıl ürünlerinin üretiminde kayda değer (en az \% 50) bir artış gerekmektedir (Fahad ve ark., 2015).

Kuraklık, stresin şiddetine bağlı olarak bitki büyümesini, morfolojisini, fizyolojisini ve verimini olumsuz etkilemektedir (Farooq ve ark., 2009). Kuraklık toleransı, bitkilerde genetik, fizyolojik ve biyokimyasal mekanizmaların bir kombinasyonunu ifade eden, son derece karmaşık ve multigenik bir özelliktir (Farooq ve ark., 2009). Çeşitli gelişme dönemlerinde, bitkiler, optimum büyüme için belirli oranlarda neme ve sıcaklığa ihtiyaç duyarlar. Bitkilerin su, besin ve $\mathrm{CO}_{2}$ ihtiyaçları, çimlenmeden başlayarak sonraki fenolojik büyüme dönemlerinde giderek artar. Karşılanan bu ihtiyaç, bitkide terleme, fotosentez ve solunum için enerji ve hammadde kaynağı olarak kullanılmaktadır (Blum, 2011). Bitkiler, sıcaklık ve kuraklık stresi altında sınırlı besin alım kapasitesine ve fotosentez etkinliğe sahiptir. Kuraklık ve sıcaklık stresi bitki dokularını (yaprak, sürgün ve başak sayısı) ve bitkinin çeşitli gelişim dönemlerini (kardeşlenme, sapa kalkma, karınlama, başaklanma, çiçeklenme ve tane doldurma) olumsuz etkilemektedir (Hossain ve ark., 2013). Yirminci yüzyılda, dünyada ortalama sıcaklık son 10 yılda $0,3{ }^{\circ} \mathrm{C}$ artmıştır ve sıcaklık artışının 2025 yılında $1^{\circ} \mathrm{C}, 2100$ yılında $3{ }^{\circ} \mathrm{C}$ üzerine çıkması beklenmektedir. $\mathrm{Bu}$ da yakın gelecekte daha şiddetli küresel iklim değişikliklerine yol açacaktır.

Bu çalışmada makarnalık buğday genotiplerinin azalan su seviyelerine tepkilerinin ölçülmesi ve su stresinden az etkilenen hatların belirlenmesi hedeflenmiştir.

\section{Materyal ve Yöntem}

Çalışma, 2019-2020 yetiştirme sezonunda Dicle Üniversitesi Ziraat Fakültesi araştırma serasında yürütülmüştür. Araştırmada 7 adet makarnalık buğday genotipi (DZ7-51, Fırat-93, Hat-300, Sena, Svevo, TBT16-7 ve TBT16-9) kullanılmıştır. Çalışma, tarla kapasitesi üzerinden oluşturulan sulama seviyeleri (\%100TK, \%75TK, \%50TK, \%25TK) ana parselleri; ele alınan genotipler ise alt parselleri oluşturacak şekilde, Tesadüf Parsellerinde Bölünmüş Parseller Deneme Desenine göre 4 tekrarlamalı olarak, 24 Mart 2020 tarihinde kurulmuştur.

Çalışma kapsamında, makarnalık buğday genotipleri sera koşullarında her saksıda 4 bitki olacak şekilde 8 It'lik saksılarda yetiştirilmiştir. Saksılara 8/10 toprak, 1/10 elenmiş yanmış çiftlik gübresi ve $1 / 10$ elenmiş kum karışımı doldurulmuştur. İçerisinde $5 \mathrm{~kg}$ toprak bulunan bir saksının tarla kapasitesini belirlemek için öncelikle saksı iyice sulanmıştır. Sulamadan sonra saksıdan fazla suyun süzülmesi için 24 saat beklenmiştir. Bu süre sonunda, su ile iyice doyurulmuş olan toprağın yaş ağırlığı belirlenmiş, daha sonra 105 ${ }^{\circ} \mathrm{C}$ 'de 24 saat kurutulup tartılarak kuru toprak ağırlığı belirlenmiştir. Yaş toprak ağırlığı ile kuru toprak ağırığı arasındaki fark toprakta tutulan su 
miktarı (tarla kapasitesi) olarak belirlenmiştir (Bilski ve Foy, 1987; Turhan ve ark., 2000). Tarla kapasitesi \% 100 olarak kabul edilip, bu miktarın $\% 75^{\prime} i, \% 50$ 'si ve $\% 25^{\prime}$ i belirlenip, artan düzeyde kuraklık stresi yaratılmıştır. Su kısıtlaması bitkilerin ekiminden itibaren uygulanmıştır. Sulama miktarlarının hassas uygulanması için zamanlayıcılı selenoid vanalar ile kontrol edilebilen damla sulama sistemi kurulmuştur. Gübre olarak saf halde $\mathrm{m}^{2 \prime}$ ye $12 \mathrm{~g}$ azot ve $6 \mathrm{~g}$ fosfor gelecek şekilde gübreleme yapılmıştır. Azotun yarısı ve fosforun tamamı ekimle birlikte, azotun diğer yarısı ise kardeşlenme döneminde uygulanmıştır. Çalışmada kullanılan toprağın bazı fiziksel ve kimyasal özellikleri Çizelge $1^{\prime}$ de verilmiştir.

Çizelge 1. Çalışmada kullanılan toprağın bazı fiziksel ve kimyasal özellikleri

Table 1. Physical and chemical properties of the soil used in the study.

\begin{tabular}{|c|c|c|}
\hline \multicolumn{3}{|c|}{$\begin{array}{l}\text { Toprak analiz sonuçları } \\
\text { Soil analysis results }\end{array}$} \\
\hline $\begin{array}{l}\text { Analiz Adı } \\
\text { Analysis Name }\end{array}$ & & \\
\hline $\begin{array}{l}\text { Saturayon (\%) } \\
\text { Saturation (\%) }\end{array}$ & 63.00 & $\begin{array}{l}\text { Killi Tınlı } \\
\text { Clay loam }\end{array}$ \\
\hline $\begin{array}{l}\text { Tuzluluk (Saturasyon Çamuru) (dS/m) } \\
\text { Salinity (Saturation Sludge) }(\mathrm{dS} / \mathrm{m})\end{array}$ & 0.92 & $\begin{array}{c}\text { Tuzsuz } \\
\text { Without salt }\end{array}$ \\
\hline $\begin{array}{l}\text { pH (Saturasyon Çamuru) } \\
\text { pH (Saturation Sludge) }\end{array}$ & 8.11 & $\begin{array}{l}\text { Hafif Alkali } \\
\text { Light Alkali }\end{array}$ \\
\hline $\begin{array}{l}\text { Kireç (Kalsimetrik) (\%) } \\
\text { Lime (Calcimetric) (\%) }\end{array}$ & 11.24 & $\begin{array}{l}\text { Orta } \\
\text { Middle }\end{array}$ \\
\hline $\begin{array}{l}\text { Organik Madde (Walkey Black) (\%) } \\
\text { Organic Matter (Walkley Black) (\%) }\end{array}$ & 0.71 & $\begin{array}{l}\text { Düşük } \\
\text { Low }\end{array}$ \\
\hline $\begin{array}{l}\text { Azot (Hesaplama İle) (\%) } \\
\text { Nitrogen (\%) }\end{array}$ & 0.04 & $\begin{array}{l}\text { Düşük } \\
\text { Low }\end{array}$ \\
\hline $\begin{array}{l}\text { Fosfor (Olsen Spektrometre) (ppm) } \\
\text { Phosphorus (Olsen Spectrometer) (ppm) }\end{array}$ & 4.00 & $\begin{array}{l}\text { Düşük } \\
\text { Low }\end{array}$ \\
\hline $\begin{array}{l}\text { Potasyum (A. Asetat-ICP) (ppm) } \\
\text { Potassium (A. Acetate-ICP) (ppm) }\end{array}$ & 314.45 & $\begin{array}{l}\text { Yüksek } \\
\text { High }\end{array}$ \\
\hline $\begin{array}{l}\text { Kalsiyum (A. Asetat-ICP) (ppm) } \\
\text { Calcium (A. Acetate-ICP) (ppm) }\end{array}$ & 10717.89 & $\begin{array}{l}\text { Çok Yüksek } \\
\text { Very High }\end{array}$ \\
\hline $\begin{array}{l}\text { Magnezyum (A. Asetat-ICP) (ppm) } \\
\text { Magnesium (A. Acetate-ICP) (ppm) }\end{array}$ & 471.78 & $\begin{array}{l}\text { Orta } \\
\text { Middle }\end{array}$ \\
\hline $\begin{array}{l}\text { Sodyum (A. Asetat-ICP) (ppm) } \\
\text { Sodium (A. Acetate-ICP) (ppm) }\end{array}$ & 26.65 & $\begin{array}{l}\text { Düşük } \\
\text { Low }\end{array}$ \\
\hline $\begin{array}{l}\text { Demir (DTPA-ICP) (ppm) } \\
\text { Iron (DTPA-ICP) (ppm) }\end{array}$ & 9.29 & $\begin{array}{l}\text { Çok Yüksek } \\
\text { Very High }\end{array}$ \\
\hline $\begin{array}{l}\text { Bakır (DTPA-ICP) (ppm) } \\
\text { Copper (DTPA-ICP) (ppm) }\end{array}$ & 1.61 & $\begin{array}{c}\text { Orta } \\
\text { Middle }\end{array}$ \\
\hline $\begin{array}{l}\text { Mangan (DTPA-ICP) (ppm) } \\
\text { Manganese (DTPA-ICP) (ppm) }\end{array}$ & 16.50 & $\begin{array}{l}\text { Orta } \\
\text { Middle }\end{array}$ \\
\hline Zinc (DTPA-ICP) (ppm) & 0.08 & $\begin{array}{l}\text { Düşük } \\
\text { Low }\end{array}$ \\
\hline
\end{tabular}

Araştırmada incelenen özellikler şunlardır: Farklı araştırıcıların (Borojevic ve Williams, 1982; Gebeyehou ve ark., 1982; Nass, 1973; Slafer ve Miralles, 1992; Spiertz ve ark., 1971) uyguladıkları yöntemler esas alınarak, aşağıda sıralanan ölçümler ve hesaplamalar yapılmıştır.

\section{Başaklanma tarihi (gün)}

Ekim tarihi ile saksıdaki bitkilerin \%50'sinde başağın bayrak yaprak kınından $1 / 2$ oranında çıktığı tarih arasındaki gün sayısı olarak hesaplanmıştır.

\section{Bitki boyu (cm)}

Sapın toprağa bağlanmış olduğu noktadan tepe başakçığın ucuna kadar olan mesafe ölçülerek belirlenmiştir.

\section{Fizyolojik olum süresi (gün)}

Ekim tarihi ile saksıdaki bitkilerin başak ve üst saplarının \%90 oranında sarardığı tarih arasındaki gün sayısı olarak belirlenmiştir. 
Klorofil metre (SPAD) değeri

Ölçüm, SPAD 502 Chlorophyll-Meter aleti kullanılarak, bitkinin başaklanma döneminde bayrak yaprağın ortasından, orta damara denk gelmeyecek şekilde 10.00-12.00 saatleri arasında ölçülmüştür.

\section{Bayrak yaprak dikliği (0-90)}

Bitkinin tüm yapraklarının ışınları daha iyi alabilmesini belirlemek amacıyla kullanılmıştır. Yaprak ayasının sapla yaptığı $0-90^{\circ}$ lik iç açı değerleri çiçeklenme döneminde görsel olarak belirlenmiştir.

\section{Mumsuluk (0-5 skalası)}

Bitkiyi serin tutma ve transpirasyonun azaltılması ve yüksek ışığın fotosentetik sürece olumsuz etkilerinin engellemesi yönünden önemlidir. Bu amaçla başak, sap ve yaprak üzerinde çiçeklenme sonrasında 0-5 skalası kullanılmış olup, bu skalaya göre 0 : gövde tamamen mumsuz yani çıplak, 5: gövde tamamen beyaz ve yoğun mum örtüsü ile kaplı olarak kabul edilmiştir.

\section{Yaprak kıvrılması (0-10 skalası)}

Kurağa dayanıklılık mekanizması olan yaprak kıvrılması bitkinin kuraklılık ile birlikte kıvrılarak açıkta kalan yüzey alanını azaltma prensibine dayanmaktadır. Tane dolumunun ortalarına doğru, bayrak yaprağında 0-10 skalası kullanılarak belirlenmiştir. 0: hiç kıvrılma yok, 10: yaprak sağdan ve soldan tamamen kıvrılarak yaprak ayasının üst yüzeyini kapatmış olarak kabul edilmiştir.

\section{Başak uzunluğu (cm)}

Her saksıdan alınan başakların boyları ölçülmüştür ve bu ölçümlerin ortalamaları alındıktan sonra başak uzunluğu hesaplanmıştır.

Başakta başakçık sayısı (adet): Her saksıdan alınmış olan başaklardan, başaktaki başakçık sayısının sayılıp ortalamalarının alınması ile hesaplanmıştır.

\section{Başakta tane sayısı (adet)}

Her saksıdan alınan başaklar harmanlanarak taneleri sayılmış ve bunların ortalamalarının alınması ile belirlenmiştir.

\section{Başakta tane ağırlığı ( $g$ )}

Hasat döneminde alınan başaklar, harman edilmiş ve hassas tartı ile tartılmıştır. Elde edilen sonuçlar $\mathrm{g}$ cinsinden tespit edilerek ortalaması alınmıştır.

\section{Bin tane ağırlığı (g)}

Her saksıdan elde edilen tanelerden rastgele 4 x 100 tane sayılarak $0.01 \mathrm{~g}$ duyarlııktaki terazide tartılıp, ortalamaların 10 ile çarpılmasıyla hesaplanmıştır.

\section{Bitki verimi $(g / b i t k i)$}

Hasat edilen bitkilerden elde edilen tane ürünü tartılarak belirlenmiştir.

Hasat indeksi (\%)

(Tane verimi x 100) / Biyomas formülü ile hesaplanmıştır.

Biyomas ( $g /$ bitki)

Saksıdan alınan tüm toprak üstü bitki kısımlarının ağırlıkları kurutulduktan sonra tartılarak belirlenmiştir.

\section{Protein Oranı (\%)}

Her saksıdan alınan örneklere ait protein oranı, GrainSense cihazında \% olarak tespit edilmiştir.

\section{Tane rengi}

Buğdayda renk $b$ değeri HunterLab ColorFlex, A60-1010-615 cihazı ile ölçülmüştür.

\section{Su kullanım etkinliği (SKElr) $(\mathrm{mg} / \mathrm{ml})$}

Toplam tane verimi miktarının verilen sulama suyu miktarına oranı olarak ifade edilen sulamaya dayalı su kullanım etkinliği (SKEır) aşağıdaki formül ile hesaplanmıştır (Li ve ark., 1995).

SKEIr $=$ TDV $/$ SM

SKEIr : Sulamaya dayalı su kullanım etkinliği ( $\mathrm{kg} /$ ton), TDV : Toplam tane verimi $\left(\mathrm{kg} / \mathrm{m}^{2}\right) \mathrm{SM}$ : Toplam sulama suyu miktarı (ton $/ \mathrm{m}^{2}$ )

Incelenen parametrelere ait elde edilen değerler JUMP Pro 13 istatistik paket programı 
yardımıyla varyans analizine tabi tutulmuş ve ortalamalar arasındaki istatistiki farklılıklar LSD testi ile ortaya konulmuştur.

\section{Bulgular ve Tartışma}

Farklı sulama seviyelerinin (\%100TK, \%75TK, \%50TK ve \%25TK) uygulandığı makarnalık buğday genotiplerinde incelenen özelliklere ait varyans analizi sonuçları çizelge 2 'de verilmiştir. İncelenen tüm özelliklerde azalan sulama uygulamalarında önemli istatistiksel farklılıklar oluşmuştur. Başakta başakçık sayısı, başak verimi ve tane verimi yönünden istatistiksel önemde genotipik farklılık meydana gelmemiştir. Tane verimi su kullanım etkinliği ve incelenen birçok özellikte sulama $x$ genotip interaksiyonu istatistiksel olarak önemli bulunarak bu özelliklerde genotiplerin değişen su miktarlarına farklı tepki verdiği belirlenmiştir.

Tane verimi, biyolojik verim ve su kullanım etkinliği haricindeki diğer özelliklerin azalan sulama suyu seviyelerindeki minimum, maksimum ve ortalama değerleri Çizelge 3'de verilmiştir.

Başaklanma gün sayısı, fizyolojik olum süresi, bitki boyu, bayrak yaprak açısı, klorofil metre değeri (SPAD), başak uzunluğu, başakta başakçık sayısı, başakta tane sayısı, başakta tane ağırlığı, tane verimi, bin tane ağırlığı, hasat indeksi, b değeri ve biyomas özelliklerinde sulama suyu artışının üretkenliği artırmasına bağlı olarak en yüksek değerler \%100TK sulama uygulamasından elde edilmişken en düşük değerler \%25TK sulama uygulamasından elde edilmiştir. Buna karşılık strese bağlı olarak artış gösteren mumsuluk, yaprak kıvrılması ve protein değerlerinde su stresi artışına bağlı olarak yükselme meydana gelmiştir.

Azalan sulama suyu seviyeleri genotiplerin erken başaklanmasına sebep olmuştur (Çizelge 3). Bitkilerin yetişme süreleri için büyük öneme sahip olan topraktaki mevcut nem yüksek tohum verimi için kritik öneme sahiptir. Blum (2007), kısa gelişme döneminin (erken çiçeklenme) özellikle geç dönemlerde oluşan kuraklıktan kaçış mekanizması olduğunu, bununla birlikte uzun gelişme döneminin genellikle daha yüksek verim potansiyeli anlamına geldiğini ve sonuç olarak erkenciliğin kuraklığın geliş dönemi önceden tahmin edilemeyen çevrelerde verimin azaltılması ile sonuçlanabileceğini, erkenciliğin daha çok tahmin edilebilir çevrelerde fenolojiyi optimize etmek için kullanılabileceğini bildirmiştir.

Çalışmada verilen sulama suyu miktarı azalmasının bitkinin vejetatif ve generatif gelişme sürelerini kısalttığı gözlemlenmiştir. Genotipler arasında Sena çeşidi özellikle \%50KT su stresinde diğer genotiplere kıyasla yaşam süresini uzatmıştır. Bu çeşit stres ortamında uzun süre fotosentez aktivitesini devam ettirdiği ve kuru madde ürettiği gözlemlenmiştir. Gebe dönem, başaklanma, çiçeklenme ve süt olum dönemlerinde bitki toprakta yeterli miktarda suya ulaştığında bitki maksimum verime ulaşır (Araus ve ark., 2002). Erkenci genotiplerin seleksiyonu, terminal kuraklık stresinin sebep olduğu verim kaybını en aza indirmek için etkili bir stratejidir (Kirda ve ark., 1999).

Bitki boyu diğer özelliklere göre su kısıtlamasına daha fazla tepki vermiştir. Tarla kapasitesinin altında verilen su miktarlarının bitkinin vejetatif süresini kısalttığından dolayı genotiplerin bitki boylarını olumsuz etkilemiştir. Poudel ve ark., (2020), kuraklığın bitki boyunu olumsuz etkilediğini, iyi sulanan genotiplerin, kuraklık stresi altındaki genotiplerden daha uzun boya sahip olduğunu ve uzun boylu genotiplerde, kurak koşullarda kısa boylu genotiplerinden daha fazla verim düşüşü yaşandığını bildirmiştir. 
Çizelge 2.Özelliklere ait kareler ortalamaları ve CV\% değerleri

Table 2. Means of squares and CV\% values of properties

\begin{tabular}{|c|c|c|c|c|}
\hline $\begin{array}{l}\text { Özellikler } \\
\text { Features }\end{array}$ & $\begin{array}{l}\text { Su Seviyeleri } \\
\text { Water Levels }\end{array}$ & $\begin{array}{l}\text { Genotip } \\
\text { Genotype }\end{array}$ & $\begin{array}{c}\text { Genotip*Su Seviyesi } \\
\text { Genotype * Water Level }\end{array}$ & $\mathrm{CV}$ \\
\hline $\begin{array}{l}\text { Başaklanma gün sayısı (gün) } \\
\text { Heading time (day) }\end{array}$ & $69.14 * *$ & $48.85 * *$ & $5.04^{* *}$ & 2.55 \\
\hline $\begin{array}{l}\text { Fizyolojik olum süresi (gün) } \\
\text { Physiological maturity time (day) }\end{array}$ & $1909.54 * *$ & $7.82 * *$ & $0.77^{\text {öd }}$ & 1.07 \\
\hline $\begin{array}{l}\text { Bitki boyu }(\mathrm{cm}) \\
\text { Plant height }(\mathrm{cm})\end{array}$ & $6090.91 * *$ & $111.51^{* *}$ & $48.95 * *$ & 5.85 \\
\hline $\begin{array}{l}\text { Bayrak yaprak dikliği (0-90 açı skalası) } \\
\text { Leaf erectness (0-90 angle scale) }\end{array}$ & $599.94 * *$ & $366.63^{* *}$ & $180.07^{* *}$ & 5.80 \\
\hline $\begin{array}{l}\text { Mumsuluk (1-5 skalası) } \\
\text { Waxiness (1-5 scale) }\end{array}$ & $2.83^{* *}$ & $2.99 * *$ & $0.79^{\text {öd }}$ & 7.47 \\
\hline $\begin{array}{l}\text { Bayrak yaprak kıvrılması (1-9 skalası) } \\
\text { Leaf curl (1-9 scale) }\end{array}$ & $119.43^{* *}$ & $1.27^{*}$ & $0.88^{*}$ & 8.11 \\
\hline $\begin{array}{l}\text { SPAD değeri } \\
\text { SPAD value }\end{array}$ & $242.83^{* *}$ & $39.35 * *$ & $16.69^{\text {öd }}$ & 6.57 \\
\hline $\begin{array}{l}\text { Başak uzunluğu }(\mathrm{cm}) \\
\text { Spike length }(\mathrm{cm})\end{array}$ & $8.77^{* *}$ & $2.27^{* *}$ & $0.21^{\text {öd }}$ & 8.01 \\
\hline $\begin{array}{l}\text { Başakta başakçık sayısı (adet) } \\
\text { Number of spikelet per spike }\end{array}$ & $108.18^{* *}$ & $2.58^{\text {öd }}$ & $3.30^{\text {öd }}$ & 12.56 \\
\hline $\begin{array}{l}\text { Başakta tane sayısı(adet) } \\
\text { Number of grains per spike }\end{array}$ & $3654.72 * *$ & $65.14^{* *}$ & $69.28 * *$ & 13.54 \\
\hline $\begin{array}{l}\text { Başakta tane ağırlığı (g) } \\
\text { Grain weight per spike }\end{array}$ & $6.83^{* *}$ & $0.07^{\text {öd }}$ & $0.14^{* *}$ & 7.58 \\
\hline $\begin{array}{l}\text { Tane verimi (g/bitki) } \\
\text { Grain yield (g/plant) }\end{array}$ & $44.65 * *$ & $0.08^{\text {öd }}$ & $0.37^{* *}$ & 13.05 \\
\hline $\begin{array}{l}\text { Bin tane ağırlığı }(g) \\
\text { Thousand grain weight }(g)\end{array}$ & $2861.93 * *$ & $120.93^{* *}$ & $41.8^{\text {öd }}$ & 9.61 \\
\hline $\begin{array}{l}\text { Hasat İndeksi (\%) } \\
\text { Harvest index (\%) }\end{array}$ & $957.67^{* *}$ & $27.10^{*}$ & $67.37 * *$ & 9.94 \\
\hline $\begin{array}{l}\text { Biyomas Verimi (g/bitki) } \\
\text { Biomass yield (g/plant) }\end{array}$ & $185.27^{* *}$ & $1.47^{*}$ & $0.79^{\text {öd }}$ & 12.70 \\
\hline $\begin{array}{l}\text { Bitki su kullanım ekinliği -verim }(\mathrm{mg} / \mathrm{ml}) \\
\text { Plant water use efficiency - yield }(\mathrm{mg} / \mathrm{ml})\end{array}$ & $0.45^{* *}$ & $0.53 * *$ & $0.43^{* *}$ & 8.98 \\
\hline $\begin{array}{l}\text { Bitki su kullanım ekinliği -biyomas }(\mathrm{mg} / \mathrm{ml}) \\
\text { Plant water use efficiency - biomass }(\mathrm{mg} / \mathrm{ml})\end{array}$ & $12.44 * *$ & $0.85 * *$ & $0.54^{* *}$ & 7.57 \\
\hline $\begin{array}{l}\text { Protein içeriği (\%) } \\
\text { Protein content (\%) }\end{array}$ & $51.72 * *$ & $7.68 * *$ & $6.07^{* *}$ & 5.15 \\
\hline $\begin{array}{l}\mathrm{b} \text { değeri }(\%) \\
b \text { value }\end{array}$ & $12.82^{* *}$ & $1.26^{*}$ & $1.30 * *$ & 2.94 \\
\hline
\end{tabular}

öd: önemli değildir, ${ }^{*} ; \% 5 .{ }^{* *}$; \% 1 seviyesinde önemlidir.

Artan su stresinin optimum yetişme koşullarına oranla bayrak yaprağının klorofil içeriğinde (SPAD değeri) önemli azalmalara neden olduğu saptanmıştır (Çizelge 3). \%100TK düzeyinde klorofil içeriği yüksek olan genotiplerin kuraklık stresi düzeylerinde de yüksek klorofil içeriğine sahip olduğu belirlenmiştir. Su, klorofil sentezi için büyük bir öneme sahiptir. Yoğun bir yağıştan sonra bitkide klorofil miktarı artar fakat kurak geçen sezonlarda ise bu oran azalır. Bitki, bünyesinde klorofil miktarını maksimum düzeyde tutabilmesi için yaprak su içeriğini yüksek tutması gerekir (Bohrani and Habibi, 1992). Kuraklık stresi, bitki klorofil ışınımında ve verimde azalışa sebep olur (Khayatnezhad ve ark., 2010). 
Çizelge 3. İncelenen özelliklere ait maks.- min. ve ortalama değerler

Table 3. Maximum, minimum and mean values of the properties examined.

\begin{tabular}{|c|c|c|c|c|c|c|c|c|c|c|c|}
\hline $\begin{array}{l}\text { Özellikler } \\
\text { Features }\end{array}$ & & $100 \%$ & $75 \%$ & $50 \%$ & $25 \%$ & $\begin{array}{l}\text { Özellikler } \\
\text { Features }\end{array}$ & & $100 \%$ & $75 \%$ & $50 \%$ & $25 \%$ \\
\hline \multirow{3}{*}{$\begin{array}{l}\text { Başaklanma gün sayısı (gün) } \\
\text { Heading time (day) }\end{array}$} & Min. & 43.12 & 42.00 & 41.00 & 40.46 & \multirow{3}{*}{$\begin{array}{l}\text { Başakta başakçık sayısı } \\
\text { (adet) } \\
\text { Number of spikelet per } \\
\text { spike }\end{array}$} & Min. & 15.59 & 15.04 & 13.58 & 9.25 \\
\hline & Maks. & 49.50 & 47.75 & 46.12 & 45.51 & & Maks. & 17.00 & 16.50 & 15.59 & 13.68 \\
\hline & Ort. & $46.16 \mathrm{a}$ & $44.80 \mathrm{~b}$ & $42.83 \mathrm{c}$ & $42.64 \mathrm{c}$ & & Ort. & $16.53 \mathrm{a}$ & $15.51 \mathrm{ab}$ & $14.49 \mathrm{~b}$ & $11.65 \mathrm{c}$ \\
\hline \multirow{3}{*}{$\begin{array}{l}\text { Fizyolojik olum süresi (gün) } \\
\text { Physiological maturity time } \\
\text { (day) }\end{array}$} & Min. & 86.40 & 82.00 & 76.75 & 67.00 & \multirow{3}{*}{$\begin{array}{l}\text { Başakta tane sayısı } \\
\text { (adet) } \\
\text { Number of grains per } \\
\text { spike }\end{array}$} & Min. & 27.88 & 21.77 & 12.09 & 4.59 \\
\hline & Maks. & 89.25 & 83.65 & 79.07 & 68.00 & & Maks. & 44.25 & 34.75 & 28.13 & 11.70 \\
\hline & Ort. & 87.78 a & $82.67 \mathrm{~b}$ & $77.65 \mathrm{c}$ & $67.10 \mathrm{~d}$ & & Ort. & 35.09 a & 29.36 b & $19.48 \mathrm{c}$ & $7.23 \mathrm{~d}$ \\
\hline \multirow{3}{*}{$\begin{array}{l}\text { Bitki boyu }(\mathrm{cm}) \\
\text { Plant height }(\mathrm{cm})\end{array}$} & Min. & 61.37 & 53.72 & 39.75 & 24.06 & \multirow{3}{*}{$\begin{array}{l}\text { Başakta tane ağırlığı (g) } \\
\text { Grain weight per spike }\end{array}$} & Min. & 1.03 & 0.79 & 0.47 & 0.07 \\
\hline & Maks. & 59.25 & 67.62 & 51.25 & 34.41 & & Maks. & 1.52 & 1.49 & 1.18 & 0.24 \\
\hline & Ort. & 64.27 a & $58.30 \mathrm{~b}$ & $46.08 c$ & $28.56 \mathrm{~d}$ & & Ort. & $1.32 \mathrm{a}$ & $1.20 \mathrm{a}$ & $0.82 \mathrm{~b}$ & $0.14 \mathrm{c}$ \\
\hline \multirow{3}{*}{$\begin{array}{l}\text { SPAD değeri } \\
\text { SPAD value }\end{array}$} & Min. & 51.21 & 47.60 & 47.70 & 43.81 & Bin tane ağırlığı (g) & Min. & 36.28 & 35.84 & 28.95 & 13.14 \\
\hline & Maks. & 56.10 & 55.47 & 55.71 & 49.00 & \multirow{3}{*}{$\begin{array}{l}\text { Thousand grain weight } \\
\text { (g) }\end{array}$} & Maks. & 44.06 & 45.46 & 44.88 & 26.76 \\
\hline & Ort. & $53.94 \mathrm{a}$ & $51.88 \mathrm{~b}$ & $50.87 b$ & $46.49 \mathrm{c}$ & & Ort. & $41.73 \mathrm{a}$ & 40.77 a & $38.01 \mathrm{a}$ & $18.77 \mathrm{~b}$ \\
\hline \multirow{3}{*}{$\begin{array}{l}\text { Bayrak yaprak dikliği (0-90 } \\
\text { açı skalası) } \\
\text { Leaf erectness (0-90 angle } \\
\text { scale) }\end{array}$} & Min. & 36.77 & 29.19 & 29.19 & 29.25 & & Min. & 20.20 & 15.83 & 9.62 & 3.29 \\
\hline & Maks. & 53.50 & 62.53 & 49.19 & 37.50 & \multirow{2}{*}{$\begin{array}{l}\text { Hasat İndeksi (\%) } \\
\text { Harvest index (\%) }\end{array}$} & Maks. & 27.40 & 24.69 & 21.61 & 20.58 \\
\hline & Ort. & 44.99 a & $42.81 \mathrm{ab}$ & $39.65 \mathrm{~b}$ & $33.62 \mathrm{c}$ & & Ort. & $24.13 \mathrm{a}$ & $19.99 \mathrm{~b}$ & $16.88 \mathrm{c}$ & $9.32 \mathrm{~d}$ \\
\hline \multirow{3}{*}{$\begin{array}{l}\text { Mumsuluk (1-5 skalası) } \\
\text { Waxiness (1-5 scale) }\end{array}$} & Min. & 2.44 & 3.25 & 3.25 & 3.50 & \multirow{3}{*}{$\begin{array}{l}\text { Protein } \\
\text { İçeriği (\%) } \\
\text { Protein Content (\%) }\end{array}$} & Min. & 20.26 & 22.22 & 22.62 & - \\
\hline & Maks. & 4.5 & 4.94 & 4.97 & 5.00 & & Maks. & 23.72 & 24.39 & 27.69 & - \\
\hline & Ort. & $3.29 \mathrm{~b}$ & $3.85 \mathrm{a}$ & $3.94 \mathrm{a}$ & $4.05 \mathrm{a}$ & & Ort. & $22.20 \mathrm{c}$ & $23.09 \mathrm{~b}$ & $25.04 \mathrm{a}$ & - \\
\hline \multirow{3}{*}{$\begin{array}{l}\text { Bayrak yaprak kıvrılması (1- } \\
9 \text { skalası) } \\
\text { Leaf curl (1-9 scale) }\end{array}$} & Min. & 2.50 & 4.23 & 6.00 & 8.00 & \multirow{6}{*}{$\begin{array}{l}\text { b değeri }(\%) \\
b \text { value }(\%)\end{array}$} & Min. & 21.83 & 20.35 & 19.95 & - \\
\hline & Maks. & 4.97 & 5.50 & 6.75 & 9.00 & & Maks. & 23.38 & 22.27 & 22.07 & - \\
\hline & Ort. & $3.40 \mathrm{~d}$ & $5.07 \mathrm{c}$ & $6.46 \mathrm{~b}$ & $8.62 \mathrm{a}$ & & Ort. & $22.59 \mathrm{a}$ & $21.45 b$ & $21.24 \mathrm{~b}$ & - \\
\hline \multirow{3}{*}{$\begin{array}{l}\text { Başak uzunluğu }(\mathrm{cm}) \\
\text { Spike length }(\mathrm{cm})\end{array}$} & Min. & 5.41 & 4.33 & 4.07 & 3.33 & & & & & & \\
\hline & Maks. & 6.59 & 5.32 & 5.38 & 5.31 & & & & & & \\
\hline & Ort. & $5.74 \mathrm{a}$ & $4.84 \mathrm{~b}$ & $4.65 b$ & $4.35 \mathrm{c}$ & & & & & & \\
\hline
\end{tabular}

Farklı sulama seviyelerinde belirlenen bayrak yaprak dikliği değerleri 33.62-44.99 arasında değişmiştir (Çizelge 3). Su stresinin arttığı uygulamalarda, Fırat-93 çeşidi hariç tüm çeşitlerde bayrak yaprağın dikleştiği gözlemlenmiştir. Yapılan korelasyon analizlerinde yaprak dikliği ile tane verimi arasında önemli istatistiksel ilişki ortaya çıkmamıştır. Suyun yetersiz olduğu kurak ve yarı kurak alanlarda bitkilerin yaprak alanı ve yapraklarının sapla yaptığı açı kurağa dayanıklııı açısından önem taşımaktadır. Özellikle kurak alanlarda büyük yaprak alanına sahip olmayan ve sapla dik açı yapan çeşitler tercih edilmelidir. Innes ve Quarrie (1987), yaprağı daha dik olan genotiplerde daha fazla tane verimi ve biyolojik verim elde edildiği gibi, tam sulama koşulları altında da dik yapraklı çeşitlerden yüksek verim elde edildiğini belirtmişlerdir.

Kuraklık stresinin derecesine bağlı olarak genotiplerde mumsuluğu arttırdığı tespit edilmiştir (Çizelge 3). Mumsu yapıya sahip çeşitlerin, mumsuzlara göre daha fazla biyolojik ve tane verimine sahip olduğu farklı çalışmalarda bildirilmiştir (Dakheel ve Makdis, 1991; Dencic ve ark., 2000). Su stresi altında, toleranslı bitkilerin kurak koşullara uyum sağlamak için yaprak mumsuluk oranını artırabilme yeteneğine sahip olduğu bu çalışmada belirlenmiştir. Kuraklığa toleransta yaprak mumsuluğu ele alınması gereken önemli özelliklerden biri olarak belirlenmiştir.

Sulama seviyelerinde belirlenen yaprak kıvrılması değerleri 3.40-8.62 arasında değişmiştir. $\% 100 T K$ ve $\% 75 T K$ sulama suyu seviyelerinde yer alan genotiplerin yaprak kıvrılması değerleri genel olarak \%25TK kuraklık düzeyindeki genotiplerin değerlerinden düşük olduğu saptanmıştır (Çizelge 3). Bu durum kuraklık stresine karşı genotiplerin evapotranspirasyon yolu ile yaprak ayası yüzeyinden su kaybını minimum düzeyde tutmak amacıyla yaprak yüzeyi birim alanını küçülterek sıcaklık stresine karşı reaksiyon göstermesinden kaynaklanmaktadır. Ayrıca bitkilerde yaprak kıvrımının artmasının klorofil miktarını azalttığı saptamıştır. Yaprak kıvrılması, yaprak kalınlığı ve yaprak dikliğinin stres koşulları altında önemli rol oynayabilecek karakterler olduğu (Skovmand ve ark., 2001), kurak koşullarda yetişen bitkilerin yapraklarında kıvrılma olmaması bitki 
bünyesindeki su durumunun ve derin kök sisteminin belirtisi olarak algılanabileceği, yağışların gecikmesi durumunda suyun tasarruflu kullanılabilmesi için yaprak bükülmesi, yaprak solması ve yaprak alanının koruması özelliklerinin önemli adaptasyon yeteneği olabileceği (Richards ve ark., 2001) bildirilmiştir.

Tam sulama koşullarında \%25TK sulama uygulamasına göre \%31.95 oranında daha yüksek başak uzunluğu değeri elde edilmiştir (Çizelge 3). Başak uzunluğuna göre genotipler arasında önemli farklılıklar olduğu (Maleki ve ark., 2008), ayrıca başak boyunun kurak koşullardan etkilendiği, başak boyuna göre kuru koşullardaki seleksiyonun sulu koşullarda da geçerli olabileceği (Tosun ve ark., 2006), agronomik özellikler bakımından genotipler arasında farklılıklar olacağı (Bahar ve ark., 2009) farklı araştırıcılar tarafından belirtilmiştir. Bildirimlerle uyumlu olarak su stresi arttıkça başak boyu olumsuz şekilde etkilenmiştir.

Araştırmada, sulama seviyelerinin başakta başakçık sayısı, başakta tane sayısı, başakta tane ağırlığı ve bin tane ağırlığına etkileri incelendiğinde, kuraklık stresindeki artışın bu parametrelere ait değerleri önemli düzeyde azalttığı anlaşılmaktadır. Başakta başakçık sayısındaki bu azalma, kuraklık stresindeki artışın başak uzunluğunu kısaltmasından kaynaklanmış olabileceği düşünülmektedir. Yüksek değerde başakta başakçık sayısı elde etmek için kuru koşullarda seleksiyonun yeterli olabilmesi ve büyük oranda sulu koşulları da temsil etmesi nedeniyle, uzun başak uzunluğuna sahip çeşitlerin hem sulu hem de kuru koşullarda avantajlı olacağı öngörülmektedir (Tosun ve ark., 2006). Buğdayda yapılan araştırmalar, kuraklık stresinin etkisiyle başakta tane bağlamayan başakçık sayısında \%82.29 oranında artış olduğunu göstermektedir (Akram ve Iqbal, 2004). Tane verimini fazla etkileyen özelliklerin başında gelen başakta tane sayısı ve başakta tane ağırlığının kurağa karşı en hassas özellikler olduğu (Dencic ve ark., 2000; Maleki ve ark., 2008) bu çalışmada da teyit edilmiştir. Su stresindeki artışa bağlı olarak olgunlaşma süresi önemli bir şekilde kısalmış, bu da tane dolum döneminin kısalmasına neden olmuş ve cılız taneler elde edilmiştir (Çizelge 3). Farklı araştırmacılar tarafından yapılan çalışmalarda da kurak koşullarda başakta tane ağırlığında azalma olduğu tespit edilmiştir. Kurak koşullarda başakta tane ağırlığı, bin tane ağırlığı ile tane verimi arasında olumlu ve önemli ilişki bulunduğu belirtmişlerdir (Maleki ve ark., 2008; Pireivatlou ve Yazdansepas, 2007; Özkan ve ark., 2018).

Araştırmada, \%100 tarla kapasitesi uygulamasında tane veriminin artması ve tane dolum süresinin uzaması hasat indeksini artırdığı belirlenmiştir. Ayrıca, başakta tane sayısı ve başakta tane ağırlığı verim unsurları da hasat indeksinin yükselmesine katkı sağlamıştır. Öztürk ve Korkut (2018), hasat indeksi açısından en yüksek oranı erken dönem kuraklık uygulamasında, en düşük hasat indeksi ise geç dönem kuraklık uygulanan parsellerde saptamışlardır. Araştırmada elde edilen sonuçlar Foulkes ve ark. (2002) ve Maleki ve ark. (2008), tarafından yapılan çalışmalardan elde edilen bulgulara benzerlik göstermiştir.

Çalışmada \%25TK kuraklık stresi uygulamalarında yeterince tohum elde edilemediğinden dolayı protein ve renk analizleri yapılamamıştır. Bundan dolayı değerlendirme yapilırken \%100TK, \%75TK ve \%50TK sulama seviyeleri dikkate alınmıştır. Sulama seviyelerinde ortalama protein oranı (\%) 22.20-25.04 arasında değişmiştir. Yetiştirme döneminde sera ortamının sıcaklığının yüksek olması bitkilerde karbonhidrat birikimini azaltmıştır. Bu sebepten dolayı tüm sulama seviyelerinde bitkilere ait protein oranı değerleri normal değerlerin üzerinde seyretmiştir. Pierre ve ark. (2008), buğdayda tane dolum döneminde farklı sulama seviyeleri uygulamasının tane proteinini değiştirdiğini belirtmişlerdir. Azalan sulama suyu seviyelerinde ortalama b renk değeri 21.24-22.59 arasında değişmiştir. Araştırmada, sulama seviyelerindeki azalışla birlikte ortalama b renk değerinin azaldığı saptanmıştır.

Su stresindeki artışın ele alınan tüm genotiplerde biyomas verimini önemli düzeyde azalttığı saptanmıştır. Tarla kapasitesi (\%100TK) 
koşullarına göre biyomas verimindeki azalmalar, \%75TK kuraklık düzeyinde \%46.5; \%50TK kuraklık düzeyinde \%75.1 ve \%25TK kuraklık düzeyinde \%91.8 olarak belirlenmiştir. Kurak koşullarda biyolojik verimin azalmasının tane verimi ile ilişkili olduğu (Foulkes ve ark., 2002), su eksikliğinin biyolojik verim ve tane verimi ile ilgili bazı özellikleri etkileyen önemli bir unsur olduğu (Öztürk ve Korkut, 2018) bildirilmiştir.

Çizelge 4. Makarnalık buğday genotiplerinin artan su stresinde tane verimi ve bitki su kullanım ekinliği değerleri Table 4. Grain yield and plant water use efficiency values of durum wheat genotypes under increased water stress.

\begin{tabular}{|c|c|c|c|c|c|c|c|c|c|c|}
\hline \multirow[b]{2}{*}{$\begin{array}{l}\text { Genotip/Su Stresi } \\
\text { Genotype / Water Stress }\end{array}$} & \multicolumn{5}{|c|}{$\begin{array}{l}\text { Tane verimi (g/bitki) } \\
\text { Grain yield (g/plant) }\end{array}$} & \multicolumn{5}{|c|}{$\begin{array}{l}\text { Bitki su kullanım ekinliği -verim }(\mathrm{mg} / \mathrm{ml}) \\
\text { Plant water use efficiency - yield }(\mathrm{mg} / \mathrm{ml})\end{array}$} \\
\hline & $100 \%$ & $75 \%$ & $50 \%$ & $25 \%$ & $\begin{array}{l}\text { Ort. } \\
\text { Mean }\end{array}$ & $100 \%$ & $75 \%$ & $50 \%$ & $25 \%$ & \begin{tabular}{|l|} 
Ort. \\
Mean \\
\end{tabular} \\
\hline DZ7-51 & $3.57 a b$ & $1.85 \mathrm{~d}-\mathrm{h}$ & $0.86 \mathrm{~h}-\mathrm{I}$ & $0.13 \mathrm{kl}$ & 1.60 & $0.61 \mathrm{~d}-\mathrm{h}$ & $0.90 \mathrm{~b}-\mathrm{e}$ & $0.78 b-f$ & $0.61 \mathrm{~d}-\mathrm{h}$ & $0.73 \mathrm{BC}$ \\
\hline FIRAT-93 & $3.03 a-c$ & $2.17 \mathrm{c}-\mathrm{f}$ & 0.76 ו-I & $0.14 \mathrm{kl}$ & 1.52 & $0.48 \mathrm{e}-\mathrm{h}$ & $0.84 \mathrm{~b}-\mathrm{e}$ & $0.66 \mathrm{~d}-\mathrm{h}$ & $0.61 \mathrm{~d}-\mathrm{h}$ & $0.65 \mathrm{C}$ \\
\hline HAT-300 & $2.77 b-d$ & $1.46 \mathrm{f}-\mathrm{I}$ & $0.96 \mathrm{~h}-\mathrm{k}$ & $0.37 \mathrm{j}-1$ & 1.39 & $0.54 d-h$ & $0.72 \mathrm{c}-\mathrm{h}$ & $0.85 \mathrm{~b}-\mathrm{e}$ & $1.19 \mathrm{a}$ & $1.08 \mathrm{~A}$ \\
\hline SENA & $2.72 \mathrm{~b}-\mathrm{e}$ & $1.9 \mathrm{~d}-\mathrm{g}$ & $1.21 \mathrm{~g}-\mathrm{j}$ & $0.19 \mathrm{kl}$ & 1.51 & $0.47 \mathrm{e}-\mathrm{h}$ & $0.97 b-d$ & $1.21 \mathrm{~b}$ & $1.14 \mathrm{bc}$ & $0.95 \mathrm{AB}$ \\
\hline SVEVO & $3.82 \mathrm{a}$ & 1.80 e-h & $0.52 \mathrm{j}-\mathrm{I}$ & $0.13 \mathrm{kl}$ & 1.57 & $0.72 \mathrm{c}-\mathrm{h}$ & $0.75 \mathrm{c}-\mathrm{g}$ & 0.50 e-h & $0.58 \mathrm{~d}-\mathrm{h}$ & $0.64 \mathrm{C}$ \\
\hline TBT16-7 & $3.44 \mathrm{ab}$ & $1.92 \mathrm{~d}-\mathrm{g}$ & $0.32 \mathrm{j}-\mathrm{I}$ & $0.08 \mathrm{kl}$ & 1.44 & $0.54 \mathrm{~d}-\mathrm{h}$ & $0.98 \mathrm{~b}-\mathrm{d}$ & $0.36 \mathrm{f}-\mathrm{h}$ & $0.32 \mathrm{gh}$ & $0.55 \mathrm{C}$ \\
\hline TBT16-9 & $3.14 a b$ & $2.18 c-f$ & II ו- 0.61 & 0.031 & 1.49 & $0.59 \mathrm{~d}-\mathrm{h}$ & $0.96 \mathrm{~b}-\mathrm{d}$ & $0.61 \mathrm{~d}-\mathrm{h}$ & $0.26 \mathrm{~h}$ & $0.60 \mathrm{C}$ \\
\hline Ort./Mean & $3.21 \mathrm{~A}$ & $1.90 \mathrm{~B}$ & $0.75 \mathrm{C}$ & $0.15 \mathrm{D}$ & 1.51 & $0.56 \mathrm{~B}$ & $0.87 \mathrm{~A}$ & $0.71 \mathrm{~B}$ & $0.67 \mathrm{~B}$ & 0.74 \\
\hline$\% \mathrm{CV}$ & \multicolumn{5}{|c|}{13.05} & \multicolumn{5}{|c|}{8.98} \\
\hline $\begin{array}{l}\text { LSD Genotip } \\
\text { LSD Genotype }\end{array}$ & \multicolumn{5}{|c|}{ öd } & \multicolumn{5}{|c|}{$0.219 * *$} \\
\hline $\begin{array}{l}\text { LSD Uygulama } \\
\text { LSD Application }\end{array}$ & \multicolumn{5}{|c|}{$0.24 * *$} & \multicolumn{5}{|c|}{$0.159 * *$} \\
\hline $\begin{array}{l}\text { LSD Gen.*Uyg. } \\
\text { LSD Gen * Appl. }\end{array}$ & \multicolumn{5}{|c|}{$0.93^{* *}$} & \multicolumn{5}{|c|}{$0.413^{* *}$} \\
\hline
\end{tabular}

öd: önemli değildir, * ; \%5. **;\% 1 seviyesinde önemlidir.

Çizelge 5. Makarnalık buğday genotiplerinin artan su stresinde biyomas ve bitki su kullanım etkinliği değerleri Table 5. Biomass yield and plant water use efficiency values of durum wheat genotypes under increased water stress.

\begin{tabular}{|c|c|c|c|c|c|c|c|c|c|c|}
\hline \multirow[b]{2}{*}{$\begin{array}{l}\text { Genotip/Su Stresi } \\
\text { Genotype / Water Stress }\end{array}$} & \multicolumn{5}{|c|}{$\begin{array}{l}\text { Biyomas Verimi (g/bitki) } \\
\text { Biomass yield (g /plant) }\end{array}$} & \multicolumn{5}{|c|}{$\begin{array}{c}\text { Bitki su kullanım ekinliği -biyomas }(\mathrm{mg} / \mathrm{ml}) \\
\text { Plant water use efficiency - biomass }\end{array}$} \\
\hline & $100 \%$ & $75 \%$ & $50 \%$ & $25 \%$ & $\begin{array}{l}\text { Ort. } \\
\text { Mean }\end{array}$ & $100 \%$ & $75 \%$ & $50 \%$ & $25 \%$ & $\begin{array}{l}\text { Ort. } \\
\text { Mean }\end{array}$ \\
\hline DZ7-51 & 7.2 & 3.24 & 1.77 & 0.54 & $3.18 \mathrm{~B}$ & $1.22 \mathrm{I}-\mathrm{k}$ & $1.62 \mathrm{~h}-\mathrm{k}$ & $1.69 \mathrm{~g}-\mathrm{k}$ & $2.53 \mathrm{~cd}$ & $1.77 \mathrm{~B}$ \\
\hline FIRAT-93 & 8.08 & 4.4 & 1.99 & 0.57 & $3.76 \mathrm{~A}$ & $1.22 \mathrm{I}-\mathrm{k}$ & $1.72 \mathrm{~g}-\mathrm{k}$ & $1.79 \mathrm{f}-\mathrm{k}$ & $2.49 \mathrm{c}-\mathrm{e}$ & $1.80 \mathrm{~B}$ \\
\hline HAT-300 & 6.11 & 2.9 & 1.91 & 0.66 & $2.9 \mathrm{~B}$ & 1.19 I-k & $1.50 \mathrm{~h}-\mathrm{k}$ & $1.74 \mathrm{~g}-\mathrm{k}$ & $3.58 \mathrm{a}$ & $2.18 \mathrm{~A}$ \\
\hline SENA & 6.95 & 3.6 & 2.44 & 0.53 & $3.38 \mathrm{AB}$ & 1.17 I-k & $1.85 \mathrm{el}$ & $2.45 c-f$ & $3.29 \mathrm{~b}$ & $2.19 \mathrm{~A}$ \\
\hline SVEVO & 7.14 & 4.03 & 1.31 & 0.7 & $3.29 \mathrm{AB}$ & $1.37 \mathrm{I}-\mathrm{k}$ & $1.60 \mathrm{~h}-\mathrm{k}$ & 1.32 I-k & $2.92 \mathrm{bc}$ & $1.80 \mathrm{~B}$ \\
\hline TBT16-7 & 6.55 & 3.36 & 1.05 & 0.54 & $2.87 \mathrm{~B}$ & $1.03 \mathrm{k}$ & $1.71 \mathrm{~g}-\mathrm{k}$ & $1.22 \mathrm{I}-\mathrm{k}$ & $2.13 \mathrm{~d}-\mathrm{h}$ & $1.52 \mathrm{~B}$ \\
\hline TBT16-9 & 5.87 & 4.09 & 1.45 & 0.39 & $2.95 \mathrm{~B}$ & 1.13 I-k & $1.81 \mathrm{f}-\mathrm{j}$ & 1.45 I-k & $2.41 \mathrm{c}-\mathrm{g}$ & $1.70 \mathrm{~B}$ \\
\hline $\begin{array}{l}\text { Ort. } \\
\text { Mean }\end{array}$ & $6.84 \mathrm{~A}$ & $3.66 \mathrm{~B}$ & $1.70 \mathrm{C}$ & $0.56 \mathrm{D}$ & 3.26 & $1.19 \mathrm{C}$ & $1.69 \mathrm{~B}$ & $1.67 \mathrm{~B}$ & $2.76 \mathrm{~A}$ & 1.86 \\
\hline$\% \mathrm{CV}$ & \multicolumn{5}{|c|}{12.7} & \multicolumn{5}{|c|}{7.57} \\
\hline $\begin{array}{l}\text { LSD Genotip } \\
\text { LSD Genotype }\end{array}$ & \multicolumn{5}{|c|}{$0.55^{*}$} & \multicolumn{5}{|c|}{$0.35^{* *}$} \\
\hline $\begin{array}{l}\text { LSD Uygulama } \\
\text { LSD Application }\end{array}$ & \multicolumn{5}{|c|}{$0.42^{* *}$} & \multicolumn{5}{|c|}{$0.27^{* *}$} \\
\hline $\begin{array}{l}\text { LSD Gen.*Uyg. } \\
\text { LSD Gen * Appl. }\end{array}$ & \multicolumn{5}{|c|}{ öd } & \multicolumn{5}{|c|}{$0.67 * *$} \\
\hline
\end{tabular}

öd: önemli değildir, *; \%5, **;\% 1 seviyesinde önemlidir.

Genotiplerin ortalama bitki tane verimi 1.39 $1.60 \mathrm{~g}$ arasında değişmiştir. DZ7-51 (6.41 g) hattı tüm kuraklık stresi seviyeleri altında en yüksek bitki tane verimine sahip genotip olmuştur. Bunu
$6.1 \mathrm{~g}$ ile Fırat-93 izlemiştir. Ancak Fırat-93 artan kuraklık stresine daha az tepki vermiştir. En düşük bitki tane verimi, Hat-300 hattında elde edilmiştir. Tüm sulama seviyelerinde ortalama bitki tane 
verimi $0.15-3.21 \mathrm{~g}$ arasında değişmiştir. Genotip $\mathrm{x}$ kuraklık düzeyi interaksiyonu incelendiğinde, ortalama bitki tane veriminin 0.03-3.82 g arasında değiştiği saptanmıştır. En yüksek bitki tane verimi, Svevo çeşidinin tarla kapasitesi (\%100TK) koşullarında; en düşük bitki tane verimi ise, TBT 16-9 hattının \%25TK kuraklık düzeyinden elde edilmiştir (Çizelge 4). Su stresindeki artış ele alınan tüm genotiplerde bitki tane verimini önemli düzeyde düşürmüştür. Tarla kapasitesi (\%100TK) koşullarına göre bitki tane verimindeki azalmalar, \%75TK kuraklık düzeyinde \%40.8; \%50TK kuraklık düzeyinde \%76.6 ve \%25TK kuraklık düzeyinde \%95.3 olarak belirlenmiştir. Kurak koşulların tane ağırlığını azaltarak verimi düşürdüğü (Guttieri ve ark., 2001), tane verimindeki artışın birim alandaki tane sayısı ve başaktaki tane sayısı ile ilişkili (Waddington ve ark., 1986; Bayhan ve ark., 2020) olduğunu belirten araştırmacıların sonuçları bu araştırmada elde edilen korelasyon sonuçlarıyla desteklenmiştir. Tüm su seviyelerinde başakta tane sayısı ve başakta tane ağırlığı verimle ilişkili bulunmuştur.

Genotiplerin verim ve biyomas parametrelerine ait ortalama su kullanım etkinlikleri değerleri sırasıyla $0.55-1.08$ ve 1.52 $2.19 \mathrm{mg} / \mathrm{I}$ arasında değişmiştir. Verim bakımından en yüksek su kullanım etkinliği değeri Hat-300 hattında en düşük değer, TBT16-7 hattında elde edilmiştir. Biyomas bakımından en yüksek su kullanım etkinliği değeri Sena çeşidinde; en düşük değer, TBT16-7 hattında elde edilmiştir. Sulama seviyelerinde verim ve biyomas parametrelerine ait ortalama su kullanım etkinlikleri değerleri sırasıyla 0.56-0.87 ve 1.19-2.76 $\mathrm{mg} / \mathrm{l}$ arasında değişmiştir. Verim bakımından en yüksek su kullanım etkinliği değeri \%75TK'lık kuraklık düzeyinde; en düşük değer tarla kapasitesi (\%100TK) koşullarında elde edilmiştir. Biyomas bakımından en yüksek su kullanım etkinliği değeri \%25TK'lik kuraklık düzeyinde; en düşük değer ise tarla kapasitesi (\%100TK) koşullarında elde edilmiştir. Sulama suyu miktarına bağlı olarak hesaplanan su kullanım etkinliği değeri kısıtlı sulama koşullarında önemli düzeyde artış göstermiştir (Şekil 3). Su stresinin şiddetine bağlı olarak su kullanım etkinliğinin artış göstermesi kısıtlı su koşullarında bitkilerin tükettiği suyu daha etkin bir şekilde kuru madde üretimi için kullandığını göstermektedir. Bu durum bitkilerin, kısıtlı su ve sert kurak koşullarında farklı adaptasyon gösterdiklerini ortaya koymaktadır. Kurak koşullarda su kullanım etkinliğinin artış gösterdiği yapılan çeşitli araştırmada ortaya konulmuştur (Tatar, 2009; Yazar ve ark., 2009).

Tüm su stresi uygulamalarının bileşkesine göre yaprak kıvrılması ile tane verimi arasında önemli negatif ilişki bulunmuştur (Çizelge 6.). Tarla kapasitesindeki sulamadan aşırı su stresine doğru gidildikçe bu negatif ilişki güçlenmiştir (Şekil 1). Teorik olarak kurak ve sıcağa karşı koruyucu mekanizma sağladığı bilinen yaprak kıvrılmasının fazla olduğu çeşitlerde tane veriminin düşme eğilimi göstermesi beklenenin dışında bir sonuç olmuştur. Bu durum yaprak kıvrılmasıyla azalan transpirasyonun fotosentetik sistemin yavaşlamasına ve toplam kuru madde üretilmesinin azalmasına neden olmasıyla açıklanabilir. Bu durumda yaprak kıvrılması yapmayı transpirasyona devam eden genotiplerin kurak şartlarda daha başarılı olduğu söylenebilir. Benzer şekilde 4 lokasyonda yürütülen çalışmada yaprak kıvrılmasıyla tane verimi ve fizyolojik olum süresi arasında ilişki bulunmamıştır (Siralut, 2005). Omarova ve ark. (1995), buğdayda kurağa dayanıklı genotiplerin seçiminde yaprak kıvrılma yeteneğini seleksiyon unsuru olarak kullanmıştır. 
Çizelge 6. Özellikler arası katsayı değerleri

Table 6. Correlation values between properties

\begin{tabular}{|c|c|c|c|c|c|c|c|c|c|c|c|c|c|c|c|c|c|c|}
\hline & TV & SKE (Verim) & SKE (Bivomas) & BV & Hİ & BS & FOS & BB & YA & Mum. & YK & SPAD & $\mathrm{BU}$ & BBS & BTS & BTA & BT & b değeri \\
\hline SKE (TV) & 0.027 & & & & & & & & & & & & & & & & & \\
\hline SKE (BV) & -0.15 & $0.466^{* 8}$ & & & & & & & & & & & & & & & & \\
\hline BV & 0.241 & -0.084 & 0.262 & & & & & & & & & & & & & & & \\
\hline Hİ & $0.516^{* *}$ & $0.500^{* *}$ & 0.288 & $0.497^{* 8}$ & & & & & & & & & & & & & & \\
\hline BS & 0.262 & -0.074 & 0.037 & $0.364^{8}$ & -0.168 & & & & & & & & & & & & & \\
\hline FOS & $0.491^{* *}$ & -0.044 & 0.221 & $0.688^{* 8}$ & $0.632^{88}$ & 0.207 & & & & & & & & & & & & \\
\hline BB & $0.653^{* *}$ & -0.049 & 0.257 & $0.72^{* 8}$ & $0.65^{* 8}$ & -0.05 & $0.717 * 8$ & & & & & & & & & & & \\
\hline YA & 0.201 & -0.031 & \begin{tabular}{|l|l|} 
& -0.17 \\
\end{tabular} & 0.261 & 0.298 & \begin{tabular}{|l|} 
\\
\end{tabular} & 0.182 & 0.12 & & & & & & & & & & \\
\hline Mum. & -0.221 & -0.022 & 0.159 & -0.252 & -0.128 & 0.056 & -0.268 & -0.285 & -0.265 & & & & & & & & & \\
\hline YK & $-0.786 * \star$ & 0.041 & $0.668^{88}$ & $-0.679 * 8$ & \begin{tabular}{|c|} 
\\
\end{tabular} & \begin{tabular}{|l|} 
\\
\end{tabular} & $-0.634^{* 8}$ & $-0.635 * 8$ & \begin{tabular}{|l|l}
$-0.386^{* 8}$ \\
\end{tabular} & 0.211 & & & & & & & & \\
\hline SPAD & $0.502 * \dot{ }$ & 0.035 & 0.263 & 0.247 & 0.252 & \begin{tabular}{|l|}
-0.079 \\
\end{tabular} & 0.195 & 0.286 & 0.211 & -0.055 & $-0.499 * 8$ & & & & & & & \\
\hline $\mathrm{BU}$ & 0.275 & -0.252 & 0.278 & 0.277 & 0.268 & $0.324^{*}$ & 0.223 & 0.166 & 0.203 & $|-0.277|$ & $-0.618^{* 8}$ & 0.198 & & & & & & \\
\hline BBS & 0.24 & -0.018 & 0.229 & 0.22 & 0.235 & 0.082 & $0.412^{88}$ & 0.197 & 0.231 & -0.278 & $-0.669 * 8$ & 0.284 & $0.497 * 8$ & & & & & \\
\hline BTS & $0.878 * *$ & 0.098 & 0.247 & 0.287 & $0.523^{* 8}$ & 0.083 & $0.673^{* 8}$ & $0.671^{* 8}$ & 0.24 & -0.213 & $-0.839 * 8$ & $0.571^{8 *}$ & \begin{tabular}{|l|l|}
$0.595^{* 8}$ & \\
\end{tabular} & 0.63788 & & & & \\
\hline BTA & $0.831^{* i}$ & 0.159 & 0.25 & 0.21 & $0.651^{88}$ & \begin{tabular}{|l|}
-0.031 \\
\end{tabular} & $0.636^{* 8}$ & $0.659^{88}$ & 0.294 & -0.17 & $-0.797 * 8$ & $0.635^{* 8}$ & $0.562^{28}$ & $0.649 * 8$ & $0.925^{* 8}$ & & & \\
\hline BT & $0.497^{* *}$ & 0.192 & 0.214 & 0.212 & $0.63^{* 8}$ & -0.227 & $0.658^{88}$ & $0.665^{* 8}$ & 0.151 & -0.117 & $-0.578^{88}$ & $0.545^{\mathrm{s}}$ & $0.338^{*}$ & $0.561^{* 8}$ & $0.553^{88}$ & $0.758^{* 8}$ & & \\
\hline b değeri & 0.311 & -0.013 & 0.123 & 0.193 & 0.14 & 0.219 & 0.154 & 0.279 & 0.115 & -0.226 & -0.243 & -0.085 & 0.158 & 0.12 & 0.21 & 0.254 & -0.229 & \\
\hline Prot. & $-0,601 * *$ & \begin{tabular}{|l|}
-0.243 \\
\end{tabular} & 0.035 & -0.194 & -0.294 & -0.201 & $-0.477 * 8 \mid$ & $-0.561^{* 8}$ & -0.169 & 0.059 & $0.4398 *$ & -0.042 & -0.129 & -0.156 & $-0.528 * 8$ & $-0.505 * 8$ & -0.041 & -0.141 \\
\hline
\end{tabular}

TV: Tane verimi/ grain yield, SKE: Su kullanım etkinliği/water use efficiency, BV: Biyomas verimi/Biomass yield Hi: Hasat indeksi/Harvest index (\%), BS: Başaklanma süresi/Heading time, FOS: Fizyolojik olum süresi/Physiological maturity time, BB: Bitki boyu/Plant height, YA: Yaprak açısı/Leaf erectness Mum: Mumsuluk/Waxiness YK: Yaprak kıvrılması/Leaf curl, BU: Başak uzunluğu/Spike length, BBS: Başakta başakçık sayısı/Number of spikelet per spike, BTS: Başakta tane sayısı/Number of grains per spike, BTA: Başakta tane ağırlığı/Grain weight per spike, BT: Bin tane ağırlığı/Thousand grain weight, Prot: Protein içeriği/Protein content, $\mathrm{b}$ değeri/b value

Kurağa ve sıcağa dayanıklılık sağladığı yaygın bir şekilde kabul edilen mumsuluk en yüksek kuraklık şiddeti haricinde (\%25TK) verimle ilişkili bulunmamıştır. Su kullanım etkinliği tüm su uygulamalarında verimle önemli seviyede ilişkili

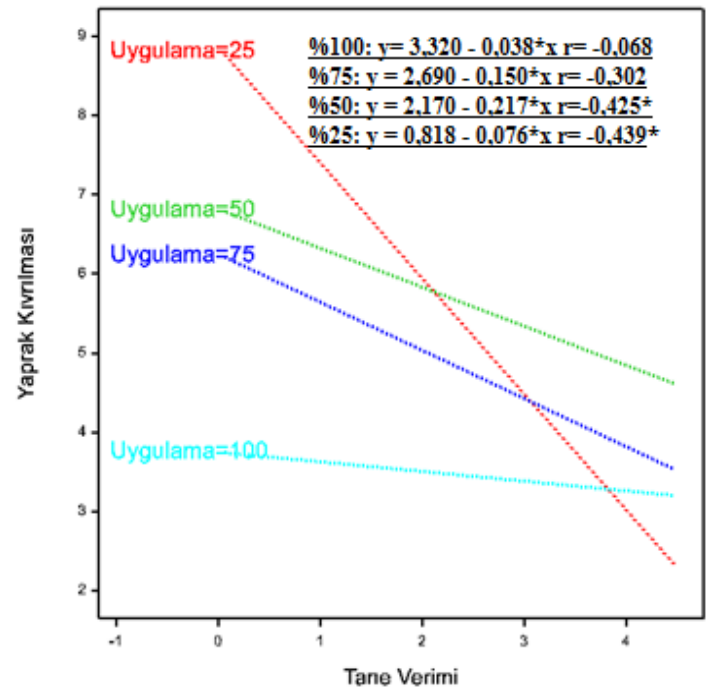

Şekil 1. Özellikler arası regresyon ilişkisi

Figure 1. Regression relationship between properties.

* ; \%5, ** ; \% 1 seviyesinde önemlidir bulunmuştur. Biyomas ile su kulanım etkinliği arasında tüm su uygulamalarında pozitif iliş̧i bulunmakla birlikte, ilişki \%75TK ve \%50TK su uygulamalarında istatistiki olarak önemli seviyededir.

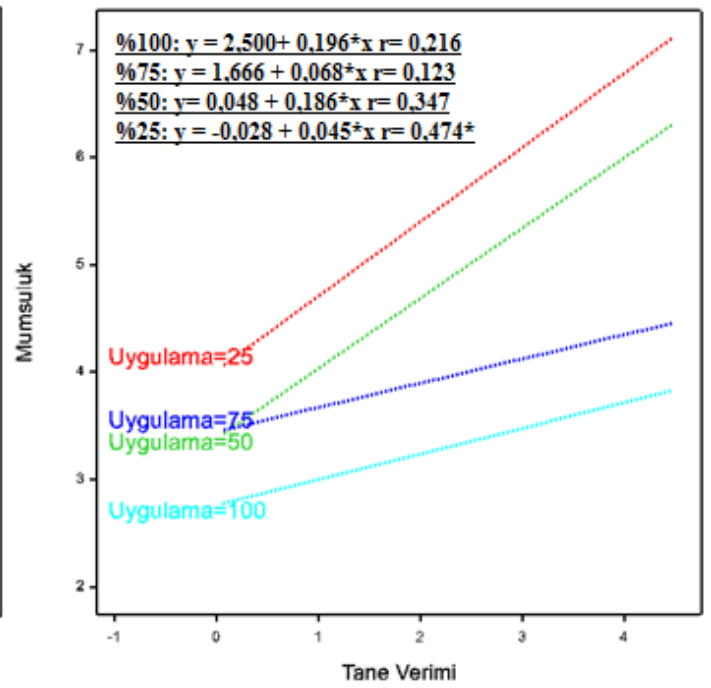



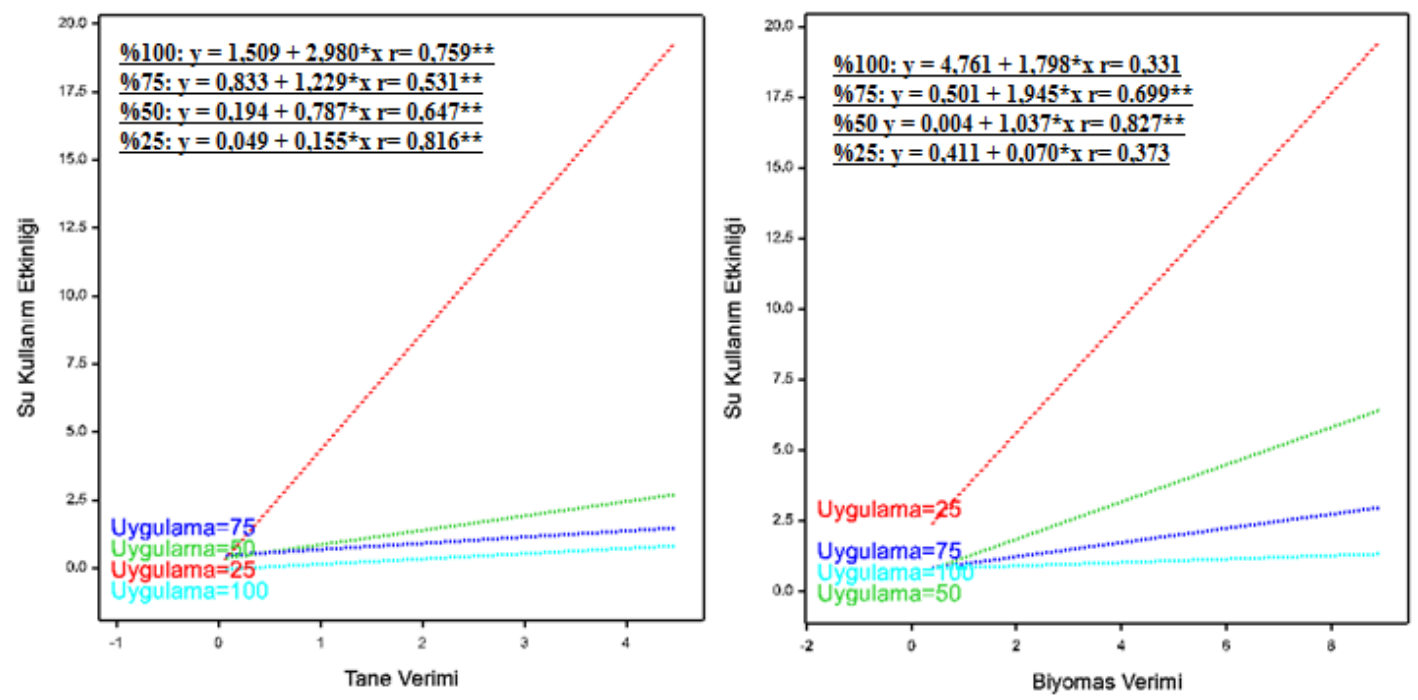

Şekil 2. Özellikler arası regresyon ilişkisi

Figure 2. Regression relationship between properties.

* ; \%5, ** ; \% 1 seviyesinde önemlidir

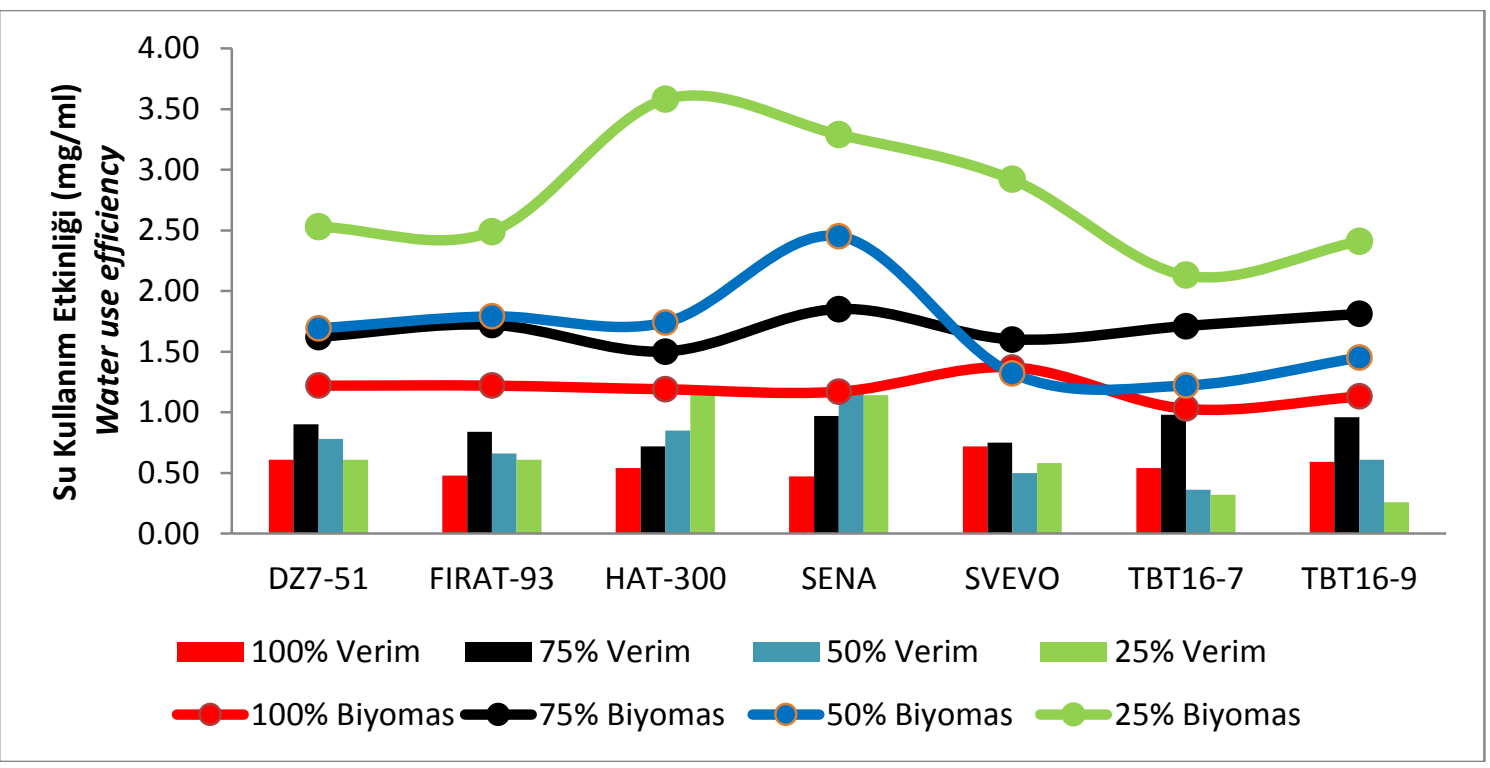

Şekil 3. Makarnalık buğday genotiplerinin artan su stresinde tane verimine ve biyomas verimine ait bitki su kullanım etkinlikleri

Figure 3. Plant water use efficiency in increased water stress of durum wheat genotypes (grain yield and biomass yield).

\section{Sonuçlar}

Elde edilen sonuçlar incelenen morfolojik ve fizyolojik özellikler içerisinde mumsuluğun kuraklığa dayanıklılıkta morfolojik markör olarak kullanılma potansiyeline sahip olabileceğini göstermiştir. Artan su stresi, genotiplerin morfolojik, fizyolojik, verim öğelerinde hızlı azalışa neden olmuştur. Hemen hemen bütün genotipler incelenen özellikler bakımından üstün performansları tarla kapasitesi koşullarında göstermişlerdir. Ayrıca verim ve biyomas açısından sulama suyu miktarına dayalı olarak hesaplanan su kullanım etkinliği değerinin kısıtlı sulama koşullarında önemli düzeyde artış göstermiştir. Artan kuraklık düzeylerinde (\%75TK dan \%25TK ya) kuru madde üretimini devam ettiren Firat-93 ( $3.07 \mathrm{~g}$ ) ve DZ7-51 ( $2.84 \mathrm{~g}$ ) genotiplerinin kurağa dayanıklılık genlerine ve gen bölgelerine sahip olabileceği ve kurağa dayanıklı çeşit geliştirme çalışmalarında dönor bitki olarak kullanılabilme potansiyeline sahip olduğu belirlenmiştir.

\section{Ekler}

Bu çalışmayı, Tübitak 1919B01190331 numaralı proje ile destekleyen Türkiye Bilimsel ve Teknolojik Araştırma Kurumu (TÜBITAK)'na teşekkür ederiz. 
Çıkar Çatışması Beyanı: Makale yazarları, aralarında herhangi bir çıkar çatışması olmadığını beyan eder.

Yazar Katkısı: Büşra AKIN, Remzi ÖZKAN, Merve BAYHAN ve Cuma $A K I N C l$ çalışmayı planlayarak denemeleri kurmuş ve çalışmayı yürütmüş, Büşra AKIN ve Remzi ÖZKAN verileri analiz etmiş makaleyi yazmıştır.

\section{Kaynaklar}

Akram H M., Iqbal M S. (2004). Drought tolerance studies of wheat genotypes. Pak. J. Biol. Sci., 7 (1): 90-92.

Araus JL., Slafer GA., Reynolds MP., Royo C. (2002). Plant breeding and drought in C3 cereals : what should we breed for ? Ann of Bot. 2002; 89(7):925-940.

Bahar B., Yıldırım M., Barutcular C. (2009). Relationships between stomatal conductance and yield components in spring durum wheat under Mediterranean conditions. Not. Bot. Hort. Agrobot. Cluj 37 (2): 45-48,

Bayhan, M., Özkan, R., Ozberk, I. (2020). Physiological, morphological, phenological and yield evaluation of durum wheat lines under rainfed conditions. International Journal of Scientific and Technological Research. 6. 31-43. 10.7176/JSTR/6-04-05.

Bilski J J., Foy C D. (1987). Differential tolerance of oat cultivars to aluminium in nutrient solutions and in acid soil of Poland. J. Plant Nutr., 10: 129-141.

Blum, A. (2007). The mitigation of drought stress Dr. Abraham Blum Web sitesi. http://www.plantstress.com. (Erişim Tarihi: 08.11.2020).

Blum, A. (2011). Plant water relations, plant stress and plant production. NY: Springer. 10.1007/978-14419-7491-4_2.

Bohrani, M., Habili, N. (1992). Physiology of Plants and Their Cells. Translation. Chamran University publication. pp. 20-34.

Borojevic, S., Williams, W. A. (1982). Genotype x Environment Interactions for Leaf Area Parameters and Yield Components and Their Effects on Wheat Yield, Crop Sci. 22, 1020-1025, 1982.

Dakheel, A., Makdis, F. (1991). The role of glaucousness as a selection criterion for drought tolerance in durum wheat. Cereal Improvement Program. Annual Report, 120-121. ICARDA, Aleppo.

Dencic, S., Kastori, R., Kobiljski, B., Duggan, B. (2000). Evaluation of grain yield and its components in wheat cultivars and landraces under near optimal and drought conditions. Euphytica 113: 43-52,

Fahad, S., Hussain, S., Saud, S., Tanveer,M., Bajwa, A. A., Hassan, S. (2015). A biochar application protects rice pollen from high-temperature stress. Plant Physiol. Biochem. 281-287. Doi: 10.1016/j.plaphy.2015.08.009.

FAO, FAOSTAT, (2011). Food and agriculture organization. Available

online at: http://faostat.fao.org/site/291/default.aspx Erişim tarihi: 10.10 .2020$.

Farooq, M., Wahid, A., Kobayashi, N., Fujita, D., Basra, SMA. (2009). Plant drought stress: effects, mechanisms and management. Agron. Sustainable Dev. 29, 185-212. Doi: 10.1051/agro:2008021.

Foulkes, MJ., Scott, RK., Brandley, SR. (2002). The ability of wheat cultivars to withstand drought in UK conditions, Journal of Agr. Sci., 138:153-169, http://cat.inist.fr/?aModele=afficheN\&cpsidt $=11312$ 29 (erişim tarihi, 17.10.2020).

Gebeyehou, G., Knott, D. R., Baker, R. J. (1982). Relationships Among Durations of Vegetative and Grain Filling Phases, Yield Components, and Grain Yield in Durum Wheat Cultivars, Crop Sci. 22, 287290, 1982.

Guttieri, MJ., Stark, JC., O’Brien. K,, Souza. E. (2001). Relative sensitivity of spring wheat grain yield and quality parameters to moisture deficit. Univ. Of Idaho Research and Extension Center, P.O. Box AA, Aberdeen, ID 83210. Crop Sci., 41: 327-335,

Haider, N. (2013). The origin of the B-genome of bread wheat (Triticum aestivum L.). Russian J. Genetics, 49, 263-274. Doi: 10.1134/S1022795413030071.

Hossain, A., Sarker, M., Saifuzzaman, M., Teixeira da Silva, J., Lozovskaya, M., and Akhter, M. (2013). Evaluation of growth, yield, relative performance and heat susceptibility of eight wheat (Triticum aestivum L.) genotypes grown under heat stress. Int. J. Plant Prod. 7, 615-636.

Innes, P., Quarrie, SA. (1987). Water Relations. Wheat Breeding. Cambridge Uni. 313-334.

Khayatnezhad, M., Zaefizadeh, M., Gholamin, R., Jamaati-e somarein Sh. (2010). Study of genetic diversity and path analysis for yield in durum wheat genotypes under water and dry conditions. World Appl. Sci. J., 9(6): 655-665.

Kirda, C,, Kanber, R., Tulucu, K. (1999). Yield response of cotton, maize, soybean, sugar beet, sunflower, and wheat to deficit irrigation. In: Crop Yield Response to Deficit Irrigations. Dordrecht, The Netherlands: Kluwer Academic. 21-38.

Li, F.M., Zhao, S.L., Duan, SS. (1995). The strategy for limited irrigation of spring wheat in semiarid Loess Plateau, China. Chin. J. Appl. Ecol. 6 (3), 259-264 (in Chinese).

Maleki, A., Babaei, F., Amin, HC., Ahmadi, J., Dizaji, AA. (2008). The study of seed yield stability and drought tolerance indices of bread wheat genotypes under irrigated and non-irrigated conditions. Research Journal of Biological Sci., 3 (8): 841-844, http://www.medwellpublishing.com/abstract/?doi= rjbsci.2008.841.844.

Nass, H. G. (1973). Determination of Characters for Yield Selection in Spring Wheat, Can. J. Plant Sci. 53, 755762, 1973.

Omarova, El., Bogdanova, ED., Polimbetova, FA. (1995). Regulation of water-loss by the leaves of soft winter-wheat with different organization of leaf structure. Russian Journal of Plant Physiology 42(3):383-385

Özkan, R., Ozberk, I., Özberk, F., Bayhan, M., 2018. Response to nitrogen and profitable variety 
preference in wheat. DUFED 7(2) 50-60.

Öztürk, i., Korkut, K. (2018). Ekmeklik buğday (Triticum aestivum L) genotiplerinde farklı gelişme dönemlerindeki kuraklığın verim ve verim unsurlarına etkisi. Tekirdağ Ziraat Fakültesi Dergisi, 15 (2), 128-137. Retrieved from https://dergipark.org.tr/tr/pub/jotaf/issue/37314/3 57122.

Pierre, CS., Peterson, CJ., Ross, AS., Ohm, JB., Verhoeven, LM., Hoefer, B. (2008). White wheat grain quality changes with genotype, nitrogen fertilization, and water stress. Agron. Journal, 100: 414-420, http://agron.scijournals.org/cgi/content/abstract/1 00/2/414 (Erişim tarihi: 17.11.2020).

Pireivatlou, SA., Yazdansepas, A. (2007). Mobilization of dry matter and its relations with drought stres in wheat genotypes. http://ses.library.usyd.edu.au/bitstream/2123/3309 /1/P208.pdf (Erişim tarihi: 21.11.2020).

Poudel, M.R., Poudel, H., Pandey, M., Thapa, D., Dhakal, K. (2020). Evaluation of Wheat Genotypes under Irrigated, Heat Stress and Drought Conditions. J Biol Today's World 2020; 9(1): 212.

Richards, RA., Condon, AG., Rebetzke, GJ. (2001). Traits to improve yield in dry environments. application of physiology in wheat breeding, International Maize and Wheat Improvement Center Mexico, D.F, CIMMYT.

Rijsberman, FR., 2006. Water scarcity: fact or fiction? Agric. Water Manag. 80, 5-22. Doi: 10.1016/j.agwat.2005.07.001.

Siralut, XRR. (2005). Leaf Rolling in wheat. PhD thesis. The Australian National University.

Skovmand, B., Reynolds, MP., Delacy, IH. (2001). Searching genetic resources for physiological traits with potential for increasing yield. application of physiology in wheat breeding. International Maize and Wheat Improvement Center Mexico, D.F,
CIMMYT. P: 17-28.

Slafer, G. A., Miralles, D. J. (1992). Green Area Duration During the Grain Filling Period of an Argentine Wheat Cultivar as Unfluenced by Sowing Date, Temperature and Sink Strength, J. Agron. and Crop Sci. 168, 191-200, 1992.

Spiertz, J. H. J., Hag, B. A., Kupers, L. J. P. (1971). Relation Between Green Area Duration and Grain Yield in Some Varieties of Spring Wheat, Neth. J. Agric. Sci. 19, 211-222, 1971.

Tatar, Ö. (2009). Buğdayda (Triticum aestivum L.) sapa kalkma döneminde meydana gelen kuraklığın başak oluşumu ve bazı fizyolojik parametreler üzerine etkisi. Türkiye VIII. Tarla Bitkileri Kongresi, 19-22 Ekim, Hatay.

Tosun, M., Yüce, S., Erkul, A., Ege, H. (2006). Kuru ve sulu koşullarda yetiştirilen buğdayın bazı agronomik ve kalite özelliklerinin direkt seleksiyona karşı indirekt seleksiyon etkinliği. Ege Üniv. Ziraat Fak. Derg., 43(2):53-62.

Turhan, H., Bager, Ġ., Önemli, F. (2000). Bazı ayçiçeği çeşitlerinin in vitro ve in vivo koşullarında kuraklık performansının belirlenmesi. Trakya Üniversitesi Araştırma Fonu, TÜAF-268, 25s.

Turral, H., Burke, J. J., and Faurès, J. M. (2011). Climate Change, Water and Food Security. Rome: Food and Agriculture Organization of the United Nations Rome.

Waddington, SR., Ransom, JK., Osmanzai, M., Saunders, DA. (1986). Improvement in the yield potential of bread wheat adapted to Northwest Mexico. Crop Sci., 26: 698-703, http://crop.scijournals.org/cgi/content/abstract/26/ 4/698.(erişim tarihi, 17.11.2020).

Yazar, A., F. Gokcel, ve Sezen, MS. (2009). Corn yield response to partial rootzone drying and deficit irrigation strategies applied with drip system. Plant Soil Environ., 55, (11): 494-503pp. 